\title{
ISSO É TRABALHO DE IMIGRANTE! APORTES SOBRE MIGRAÇÃO, GÊNERO E TRABALHO NO PRIMEIRO TESTAMENTO
}

\author{
Lília Dias Marianno*
}

\begin{abstract}
Este artigo apresenta uma abordagem bíblica que dialoga com migração, trabalho e identidade. Privilegia a abordagem de gênero e a perspectiva africana e caribenha de interpretação do texto bíblico. A provocação inicial e final é a experiência de migração de brasileiros no exterior e de estrangeiros migrantes no Brasil. O migrante, em condição servil, de pobreza e marginalização sempre faz o trabalho que os autóctones não querem mais fazer. A menina-serva de Naamã (2 Rs 5,1-27) e o eunuco-etíope-servo do palácio de Zedequias (Jr 38,1-13), personagens sem nome, foram instrumento de libertação para aqueles que lhes eram próximos por meio do seu trabalho.
\end{abstract}

Palavras-chave: Migração; Trabalho; Identidade; Gênero; Negritude.

\section{Introdução}

Desembarquei em Los Angeles com olhos de suspeita, pois já estava refletindo sobre o assunto deste ensaio. No dia seguinte seria o "Dia de Colombo", quando se celebra o descobrimento da América, data que não celebramos no Brasil (como se não fôssemos continente americano!). Viajei para os EUA devido a um colóquio sobre Anti-Imperialismo, promovido por um núcleo de pesquisadores do Centro de Estudos Processuais da Universidade de Claremont. O tema do colóquio era muito instigante, o círculo de pesquisadores era brilhante. Ter chegado ao país enquanto

\footnotetext{
Missióloga e exegeta, Mestre em Teologia Bíblica pelo STBSB onde atuou por onze anos como pesquisadora e docente, Mestre em Ciências da Religião pela UMESP. Desde 2008 integra a diretoria da ABIB - Associação Brasileira de Pesquisa Bíblica. É administradora pela UNESA, dirige a Eagle Gestão de Ensino, coordena a Pós-Graduação em Exegese Bíblica do Centro Universitário UNIABEU onde leciona nos cursos de Administração e Gestão de Recursos Humanos. E-mail: lilia. marianno@gmail.com. Rio de Janeiro/Brasil.
} 
acontecia o acampamento do movimento Occupy Los Angeles ${ }^{1}$ e os assuntos discutidos ali agregaram enorme valor ao meu posicionamento político diante das medições de forças entre as potências internacionais e os países em desenvolvimento.

Meu olhar atento foi impactado por duas realidades migratórias muito evidentes. Primeiramente, o número gigantesco de chineses desembarcando na costa oeste dos EUA na categoria de residentes. Durante minha espera de quase duas horas na aduana, milhares de pessoas transitavam no mesmo saguão. Cerca de 90\% tinham passaporte chinês e pelo menos metade se dirigia não à fila de turistas, mas à fila de residentes.

Minha vivência com a comunidade chinesa no Brasil na década de 80 me fez conhecer a dura realidade dos imigrantes chineses que por aqui passavam. Saíam da China com objetivo de morar nos EUA, "o grande sonho de todo chinês", usando as palavras de um amigo. Mas devido às questões que dominavam a relação entre os países na época da guerra fria, muitos destes chineses acabavam morando no Brasil por vários anos antes de mudar definitivamente para os EUA. Agora percebia uma multidão de chineses residentes nos EUA, isso porque fiquei apenas duas horas naquele saguão. Uma proporção inimaginável três décadas atrás. Uma notícia que ouvi algumas semanas mais tarde fez todo sentido. Durante a reunião da cúpula do G20 em Cannes, a China se comprometeu em investir um trilhão de Euro para o equilíbrio financeiro dos países em colapso econômico na Europa. ${ }^{2}$ Diante do cenário que contemplei semanas antes, imediatamente compreendi de que forma os EUA estavam sobrevivendo à crise econômica: o capital asiático entrando no país.

Meu segundo impacto com a questão migratória se deu em San Francisco, alguns dias depois, quando visitei uma comunidade brasileira. Fiquei hospedada na casa de uma família de cariocas conterrâneos e fui generosamente cuidada por eles. Tive alguns dias para visitar as ruas de San Francisco e observar a enorme quantidade de "homeless" (não pareciam estrangeiros) daquela cidade. Muita gente suja e destituída morando nas ruas, como os nossos sem-teto, mas numa cidade bem menor que o Rio de Janeiro.

À mesa, com a família anfitriã, ouvi as histórias do sofrimento, da enfermidade gravíssima que afetou a filhinha recém-nascida do casal, da outra enfermidade que afetou o pai da família, deixando-o, por muitos meses, totalmente impossibilitado de trabalhar. Os parentes é que os visitavam a

\footnotetext{
1 "Occupy Los Angeles. Occupy wall streets comes to downtown L.A.! We are the 99\%. This is direct democracy". Declaration of occupation. Disponível em: http://occupylosangeles.org/?q=declaration.

2 "Europeus estão preocupados com o que a China pedirá em troca", in Isto é dinheiro. Publicado em 27/11/2011.
} 
partir do Brasil a fim de evitar que qualquer movimento suspeito denunciasse a situação migratória irregular da família, que sofreria ainda mais caso fossem pegos pela imigração num momento como aquele. Que situação! Em terra estranha, sem parentes, e doentes. Quanto sofrimento passa um migrante!

Meus anfitriões moravam numa linda casa própria, muito bem mobiliada, construída durante treze anos de muito trabalho. À mesa, com o chefe da família, perguntei-lhe como era abandonar uma carreira no Brasil com formação superior completa para morar num país complicado para imigrantes e realizar definitivamente serviços como: pedreiros, faxineiras, manicures, babás e instaladores de carpetes e acabamentos. O meu anfitrião respondeu: "a gente vai para cá por escolher um padrão de vida que jamais teríamos no Brasil. O trabalho que fazemos aqui o americano não quer fazer. Cuidar de casa, pregar carpetes, cuidar de filhos dos outros ou ser acompanhante de gente doente? Isso não. Isso é trabalho de imigrante!" Depois conheci outro brasileiro, dono de uma empreiteira, residente em San Francisco há vinte anos, com uma situação econômica bastante privilegiada, mas vinte anos atrás chegara à Califórnia como pedreiro.

A fala do meu anfitrião, dentro de contexto tão específico inspira meu diálogo com o texto bíblico neste ensaio.

O Primeiro Testamento é um compêndio sobre migrações. Conta a história de gente constantemente em trânsito. Se fizermos uma relação de personagens que tiveram que, em algum momento, viver como migrantes, teríamos uma lista muito grande. Ló, o arameu é quem regula a justiça na cidade de Sodoma. Agar, a concubina de Abraão é uma egípcia obrigada a viver em Canaã. Jacó o cananita, em Arã era um pastor, foragido de uma briga de família que quase deu em morte. Moisés, o egípcio, vivendo na península do Sinai era um assassino refugiado. Noemi viveu como migrante em Moabe, depois Rute viveu como migrante em Belém. Quando fugia de Saul, Davi viveu como migrante no território de Moabe e também dos filisteus. Hulda no bairro novo de Jerusalém evidencia a comunidade de migrantes do norte que veio para Judá depois da ocupação da Assíria em 722. Isso para mencionar apenas alguns exemplos.

Quero conversar com um homem e uma mulher do Antigo Israel. Ambos migrantes, ambos fazendo trabalho que os autóctones não queriam fazer. Ela, imigrante de Israel vivendo em outra nação. Ele, imigrante de outra nação vivendo em Israel. Trabalham como servos de alguém. Normalmente não os consideramos como heróis. Na verdade, nem os narradores bíblicos lhes deram grande importância e raramente ouvimos sobre eles em pregações 
ou estudos bíblicos. Tenho que fazer uso de recursos do bibliodrama ${ }^{3}$ para conhecê-los melhor.

Procurei privilegiar as pesquisas de exegetas negros e negras, latinos e africanos, que também trabalham sob a perspectiva de gênero, para me auxiliarem nesta análise. Estas experiências antagônicas nos darão uma perspectiva interessante sobre a experiência do migrante bíblico e dos nossos dias. Então, vamos às descobertas.

\section{A menina sem nome (2 Rs 5,1-27)}

A menina sem nome foi uma pré-adolescente, capturada do norte de Israel em uma das muitas incursões da Síria durante os dias de Eliseu, no séc IX aEC. As relações de amor e ódio entre Samaria e Síria eram oscilantes. Ora estavam em aliança, ora estavam em enfrentamento. Essa menina passou a trabalhar na casa de um general sírio chamado Naamã. O nome dela, ninguém lembra, por que lembraria? Ela era só uma migrante e escrava.

É interessante como o texto bíblico descreve o patrão desta menina. “Naamã era grande homem diante do seu senhor... porque por ele o Senhor dera vitória à Síria". O autor bíblico faz deste general estrangeiro um servo de Deus, agindo a favor da Síria e contra Israel. Este é um dos fortes indícios que a literatura dos Profetas Anteriores realmente tem origem nos círculos que dão suporte aos profetas, pois os profetas anunciavam os povos invasores do norte como enviados de lahweh para corrigir Israel.

Da menina o texto bíblico fala muito pouco. Uma tradução mais literal registraria o texto desta forma: E[de] Aram, tropas capturaram da terra de Israel uma menina pequena, e ela esteve diante da mulher de Naaman. E disse à senhora dela: esteja meu senhor diante do profeta em Samaria, então o retirará da lepra (2Rs 5,2-3).

A ausência de narrativas sobre episódios de lepra em Israel durante o período tribal e monárquico mostra-nos que lepra não era uma doença muito conhecida dos israelitas, não se sabia muito sobre ela em Israel, pois lepra era doença de estrangeiro. ${ }^{4}$ As leis levíticas a respeito da Lepra ainda não tinham sido redigidas nos dias de Eliseu. Estas leis tiveram origem nos círculos sacerdotais e sua redação (Lv 11-19) pertence ao período pós-exílico tardio.

\footnotetext{
${ }^{3}$ O Bibliodrama é derivado do psicodrama, metodologia terapêutica ainda pouco usada no Brasil e que tem frutificado nas leituras bíblicas da comunidade. "O bibliodrama coloca-nos no caminho para um encontro com o sagrado e acende e desperta algo que há em nós, profundo como o mundo: nossa autenticidade mais plena e nossa humanidade mais divina" (ROESE, Anete. Bibliodrama: a arte de interpretar textos sagrados. São Leopoldo: Sinodal, 2007. A citação é da introdução, na p. 7).

4 Lepra no contexto do Primeiro Testamento é um conjunto de infecções cutâneas de origem indeterminada, não sendo precisamente a hanseníase conhecida em nossos dias.
} 
Ali os israelitas tiveram muito contato com povos estrangeiros e conseguiram, de algum modo, estabelecer um diagnóstico preliminar mais seguro sobre a lepra e o roteiro profilático de Lv passou a integrar o código sacerdotal. Os sacerdotes no pós-exílio desempenhavam uma importante função de vigilância sanitária e controle de epidemias. ${ }^{5}$

As narrativas sobre a prova de Moisés (cf. Ex 4,6) ou sedição de Miriã (cf. Nm 12,10) nos textos da Torá, tiveram sua redação no período pós-exílico. Por isso, a narrativa sobre Naamã, por pertencer aos Profetas Anteriores, faz parte da tradição literária mais antiga de Israel. Seus primeiros relatos tiveram origem pelo menos quatrocentos anos antes da Torá, no Norte, antes da invasão da Assíria, antes do séc. VIII aEC.

Como ama da mulher de Naamã, a menina servia à intimidade desta mulher. Por certo ouvira sua senhora se queixar constantemente do corpo de seu marido. Talvez tenha visto a repulsa que ela sentia. Se os estrangeiros possuíam alguma noção sobre o contágio da lepra, é provável que, após cada relação sexual com seu marido, a mulher de Naamã se apressasse em se banhar por inteiro para não ser contaminada com as secreções da pele de seu marido que, por certo, grudavam à pele dela durante o ato sexual. $\mathrm{O}$ banho da mulher de Naamã depois do ato deveria ser um banho cheio de cuidados especiais.

Pode ser também que, justamente para não ter contato com a pele de Naamã, sua mulher tivesse que usar alguma espécie de tecido protetor no corpo, ou ainda a relação sexual passasse por práticas bastante incomuns, tudo por conta daquela praga: a lepra. E cuidar destes detalhes era a função cotidiana da pequena menina israelita. Amas eram criadas para trato corporal de suas senhoras. Limpar secreções de pele leprosa do marido no corpo de uma mulher sã não era trabalho que a gente da terra quisesse fazer, era trabalho de imigrante!

A menina capturada realizava este trabalho deplorável constantemente. O texto bíblico não relata qualquer murmuração desta menina em seu trabalho. Como gente miúda provavelmente seu coração ainda guardava bastante da inocência infantil, e, não estando repleto das injúrias dos adultos, que certamente queriam mais a morte de Naamã e de todo o exército da Síria do que sua restauração, testemunhava o estado deplorável e vexatório de sua senhora e sentiu compaixão. Uma compaixão que gente nenhuma da terra quis sentir. Uma compaixão que provavelmente nunca haviam demonstrado

Cf. MARIANNO, Lília Dias. "Impureza: Sexualidade e saúde pública no judaísmo do período Persa", p. 110-130. 
com a menina. Então ela deu uma sugestão: procure o profeta, ele tirará o seu marido da lepra.

O restante da história é conhecida. Naamã pediu autorização ao rei da Síria, foi para Israel, procurou o rei, que ficou indignado pensando tratar-se de motivo para guerra. Foi depois até o profeta, que nem o recebeu, mas mandou o recado para que ele se banhasse no Jordão. Insultado, Naamã desejou ir embora até que um de seus companheiros o convenceu a banhar-se no Jordão. Naamã teve que se despir na frente de toda sua comitiva, expor toda aquela lepra que ficava oculta sob as armaduras, e se banhar no rio, mas foi curado.

Nosso foco aqui não é Naamã, mas sim o que aconteceu com ele por ter atendido à fala de uma garotinha imigrante que dava banho em sua esposa. Ouviu a menina, atendeu ao profeta, ficou sarado de uma doença até então incurável.

\section{O eunuco etíope (Jr 38,1-13)}

Costumamos chamá-lo de Ebed-Melech, mas esse não deve ser o seu nome real porque ebed ${ }^{6}$ significa servo e melech significa rei. Algumas versões em português preferiram traduzir a expressão como um substantivo próprio, mas em nossa visão orientada pela perspectiva africana, Ebed-Melech é um nome genérico para qualquer servo do rei. ${ }^{7}$ Isso nos leva a ter um segundo migrante desprovido de identificação nominal na literatura bíblica.

Se o eunuco teve, na Etiópia, um nome de guerreiro ou de príncipe, ninguém sabia. Todos o chamavam de "o cuchita". Provavelmente a menina também era chamada apenas de "a israelita". Essa anulação de identidade é um hábito quase que inerente ao processo de migração imposto pelo simples fato de se ser forasteiro em terra estranha e ter que abrir mão de sua cultura em prol da nova. Os processos migratórios despersonificam os migrantes. Para adentrar no outro país o migrante deixa de ser conhecido por seu nome de origem e passa a ser rotulado por sua nacionalidade. Isso acontece nos dias atuais, mas acontecia também na antiguidade. Outros migrantes da Bíblia também ficaram conhecidos pela sua distinção autóctone. Quando alguém lembrou de seus nomes, o fez acompanhado da nacionalidade, como se fossem sobrenomes: Rute - a moabita, Elias - o tisbita, Naamã - o sírio, as mulheres heteias de Esaú e assim por diante.

Jeremias foi jogado numa cisterna construída num espaço subterrâneo para armazenar água da chuva, ficando emperrado na lama. ${ }^{8}$ Tudo isso

\footnotetext{
${ }_{6}$ A expressão ebed pode ser usada para mostrar dependência de pessoas ou até mesmo de lahweh. DREHER, Carlos. "Escravos no Antigo Testamento", p. 16.

COULIBALY, Issiaka. “Comentário sobre Jr 38,1-14", p. 931-932.

8 Ibidem, p. 932.
} 
porque profetizou ao rei coisas indesejáveis: "a destruição do lugar seria inevitável". Zedequias era um rei vacilante. Tentou alianças com o Egito indo contra as orientações de lahweh por meio do profeta. Isso despertava cada vez mais a fúria de Nabucodonozor, rei da Babilônia, que mesmo deportando os judaítas, não visava destruir Jerusalém primariamente. Esta destruição foi praticamente consequência das alianças feitas por Zedequias com o Egito.

Coulibaly trata o cuchita como um empregado servil ${ }^{9}$, enquanto Ventura prefere vê-lo como um membro da corte com algum nível de poder e privilégio. Para Ventura este cuchita seria um tipo de oficial do exército com certa autoridade. ${ }^{10}$ Há algumas ocorrências de cuchitas nos exércitos israelitas e este, que ajuda Jeremias, age com muita autonomia para um empregado serviçal: “... A participação, ou melhor, a presença de cuchitas na monarquia foi uma realidade que parece ter tido a ver com a atividade não só profética, mas também militar..."11. Mas a autonomia deste cuchita me parece ter origem em outros aspectos que mencionarei adiante.

Quanto ao tipo de trabalho servil do cuchita, o conceito de servo/ escravo no Primeiro Testamento é bem diferente do conceito de servo/escravo conhecido pela civilização ocidental, e está diretamente relacionado com o Modo de Produção e com a forma com a qual uma determinada sociedade organiza sua vida material. ${ }^{12} \mathrm{O}$ servo/escravo dos tempos bíblicos era alguém que passou a esta condição por diversos motivos: capturado como prisioneiro de guerra, vendido como pagamento de dívidas com terceiros ou dívidas tributárias, mas em geral era alguém que alugava sua força de trabalho. ${ }^{13}$ Uma pessoa não se tornava escrava por questões raciais. Apenas a partir das dominações grega e romana é que o mundo bíblico conheceu o escravagismo propriamente dito. ${ }^{14}$

Além dos aportes etimológicos, sociais e teológicos, há um último aporte relevante que normalmente não é abordado sobre o cuchita: o de gênero. Esse aporte nos ajuda a entender porque, mesmo sendo um serviçal, o cuchita tinha bastante autonomia sobre o ambiente doméstico do palácio, que seria normalmente dominado por uma mulher. Ele era um eunuco e eunucos eram personagens ligados à prostituição sagrada nos cultos de Ashera. ${ }^{15}$ Os

\footnotetext{
9 Ibidem.

${ }^{10}$ VENTURA, Maria Cristina. "Um cuchita fala como o Deus do profeta! Uma leitura de Jeremias 38,7-13", p. 71-72.

${ }^{11}$ Ibidem, p. 74.

12 DREHER, op. cit., p. 10.

${ }^{13}$ Ibidem, p. 17.

${ }^{14}$ Ibidem, p. 9.

${ }^{15}$ MONTALVÃO, Sérgio Aguiar. A homossexualidade na Bíblia Hebraica. Um estudo sobre a
} 
eunucos são interpretados como homossexuais pela hermenêutica bíblica de orientação gay. ${ }^{16}$ Sendo ou não um homossexual é importante considerar que se tratava de um serviçal, muito provavelmente ligado às atividades domésticas, vinculado com o culto a Ashera, porém dentro do palácio do rei de Judá - que supostamente era javista - evidenciando o sincretismo tão condenado na literatura profética.
A presença de eunucos em ligação com os cultos do Oriente Próximo em terras mediterrâneas orientais é amplamente atestada por antigos historiadores. O deus emasculado era representado por esses equivalentes humanos, que através do sacrifício de sua virilidade se tornaram, de acordo com a crença, mais convenientemente preparados para representar a deidade para a função da adoração fálica ou para assegurar a fertilidade nos campos. Em algumas partes existiam tanto homens eunucos quanto hieródulas sem fins reprodutivos, especialmente quando a deusa era considerada como uma hermafrodita, como era Ishtar. ${ }^{17}$

O eunuco era um homem emasculado, comumente colocado em afazeres domésticos, que seriam normalmente atividades de mulheres: buscar água em poços e cisternas era uma delas. Esse seria um motivo muito lógico pelo qual ele rapidamente ouve que jogaram Jeremias na cisterna. $\mathrm{O}$ fato de poder interpelar junto ao rei demonstra que ele tinha poder para questionar o rei, então pode se supor que fosse um funcionário íntimo do monarca, com algum nível de liberdade, pois o rei o acata sem reservas. ${ }^{18}$

Prontamente o cuchita mobiliza trinta pessoas (muita gente!) para aquela empreitada e dá instruções detalhadas sobre os pedaços de pano para retirar Jeremias de dentro da cisterna com ternura. "Os panos utilizados não são novos, são velhos; mas embora velhos, têm uma função fundamental que é aliviar a dor. Então, estes panos cumprem a função de Javé, de um Javé que se manifesta humildemente para aliviar o sofrimento do profeta".$^{19} \mathrm{O}$ eunuco sabia onde encontrar estes materiais e teve a delicadeza de providenciar os panos para colocar sob os braços a fim de não ferir o profeta durante a retirada.

prostituição sagrada no Antigo Oriente Médio.

${ }^{16}$ Obra representante desta abordagem: HELMINIAK, Daniel. O que a Bíblia realmente diz sobre a homossexualidade.

${ }^{17}$ MONTALVÃO, op. cit., p. 70.

${ }^{18}$ Embora esta autora lance dúvidas sobre o fato de Israel praticar castração de seus serviçais, concordamos $\mathrm{cm}$ ela quanto ao ouvir do eunuco ser um ouvir ativo, que dá ordem a outros, com forte influência no reino, talvez o círculo de suporte do próprio profeta Jeremias (cf. MENA LOPEZ, Maricel. "Ebed-Melec, o cuchita, salva Jeremias da cisterna. Um testemunho de seguimento profético no tempo do cerco e queda de Jerusalém (Jeremias 38,7-13 e 39,15-18)", p. 46-48).

${ }^{19}$ Ibidem, p. 52. 
Era um serviçal com intimidade com os afazeres da casa e do palácio, sabendo não apenas onde se guardam as peças de rouparia, mas com sensibilidade para pensar no sofrimento do profeta, interceder junto ao rei. Não me parece bem um militar forte e poderoso: o aporte de gênero me acrescenta mais.

Lá estava o etíope, caminhando, ou indo ao poço buscar água, e quem está lá? Jeremias, atolado na lama. Quem vai fazer o trabalho sujo de retirar do poço e limpar o profeta cheio de limo, fungos, sanguessugas? Ninguém da terra quer fazer esse trabalho, isso é trabalho de estrangeiro!

Não estou aqui para enfatizar o papel de Jeremias, quero apenas chamar a atenção para o fato que, se o eunuco não tivesse retirado esse profeta daquele poço, provavelmente não teríamos o livro de Jeremias hoje no cânon, já que o profeta não teria sobrevivido para receber mais revelações nem para preservar os escritos que depois receberam seu nome. Houve uma palavra libertadora de lahweh direcionada para o cuchita que, dentro da perspectiva de gênero, é muito provocativa:

Vai e dize ao cuchita Ebed-Melec: assim disse lahweh dos Exércitos, o Deus dos exércitos, o Deus de Israel: Eis que vou cumprir contra esta cidade as minhas palavras, para desgraça e não para salvação. Naqueles dias elas se realizarão diante de teus olhos. Mas eu te livrarei neste dia e não serás entregue nas mãos dos homens, diante dos quais tu temes. Sim, certamente eu te farei escapar e não cairás sob a espada, terás a sua vida como despojo, pois em mim puseste a tua confiança (Jr 39,16-18).

Nem Zedequias, o rei, recebeu tal promessa. Ainda que o cuchita fosse um adorador de outros deuses e vivesse no palácio como servo do rei para serviços religiosos ou até mesmo sexuais, uma vez que as leis restritivas de coito entre homens ainda não estavam redigidas nesta época, esse eunuco imigrante, pela sua ação de compaixão, demonstrou ter temor de lahweh, algo que nem o rei demonstrara, e por isso escaparia da morte no dia da destruição.

\section{As leis sobre migrantes em Israel ${ }^{20}$}

Ao longo da Bíblia Hebraica percebemos que o estrangeiro ocupava um status marginal. Na legislação ele aparece com os mesmos direitos da viúva, do órfão e do levita. Era uma classe de gente que precisava ser protegida pelas pessoas com melhores condições sociais, pois o projeto para

${ }^{20}$ Obras usadas na análise etimológica: HARRIS, Laird et alii. Dicionário de Teologia do Antigo Testamento. São Paulo: Vida Nova, 1998; KIRST, Nelson et alii. Dicionário hebraico-português e aramaico-português. Petrópolis/São Leopoldo: Vozes/Sinodal, 2006; SCHÖKEL, Luis Alonso. Dicionário bíblico hebraico-português. São Paulo: Paulus, 1997; SICRE, José Luiz. Introdução ao antigo testamento. Petrópolis: Vozes, 1995. 
Israel era de que não houvesse pobres no meio do povo, ou seja, pelo jeito, o estrangeiro era sempre um pobretão no meio da nação. Israel fora estrangeiro no Egito e as situações de escravidão e opressão vividas por lá jamais deveriam se repetir no meio do povo de lahweh e nem na terra da promissão. ${ }^{21} \mathrm{No}$ texto hebraico várias palavras aparecem para designar o estrangeiro. As mais frequentes são: gér - gérim, gôy - gôyim, nokherî - nokherî̂ot, em formato singular e plural respectivamente.

gér - gérim - em geral é traduzido como forasteiro, peregrino ou migrante. Era um marginal na sociedade israelita, porém protegido por leis que regiam os direitos do pobre, da viúva e do órfão (Lv 19,10; 23,22; Dt $14,29 ; 16,11.14 ; 24,17 ; 26,13 ; 27,19)$. Entre os direitos do ger estavam a alimentação dos frutos da agricultura que fossem deixados para trás e ser julgado com justiça, podendo inclusive se refugiar nas cidades com este fim (Dt 24,19-21, Dt 1,16; 24,17; 27,19; Nm 35,15). O ger poderia ter participação ativa na vida religiosa da nação (Dt 16,14; 31,12; Ex 12,9.48, Nm 9,14; Lv $16,29)$. Considerava-se gér também o migrante de outra tribo de Israel. O gér usufruía do dízimo trienal (Dt 14, 28-29; 26,12-13) e seria maldito aquele que pervertesse seus direitos (Dt 24,14). Os israelitas não deveriam oprimir o gér porque estiveram em mesma situação no Egito (Ex 22,21; Dt 10,19). Deveriam amar o gér como a eles mesmos (Lv 19,34), porque o gér também era amado por lahweh (Dt 10,18). O próprio nome do filho de Moisés, Gerson, refere-se ao estado forasteiro em que Moisés viveu no Sinai. Estamos falando de estrangeiros que estão de passagem, gente de fora que, por força das circunstâncias necessita residir temporariamente em Israel. O gér estava sempre ali, por um tempo curto ou longo, mas não definitivo.

gôy - gôyim, é definido como povo, nação, gentio, pagão e a pluralização deste substantivo é usada para transmitir a concepção de povos pagãos. É difícil obter uma definição exata da palavra. A expressão não pode ser aplicada apenas a estrangeiros, pois também é sinônimo para 'am = povo, mas é uma expressão que dá uma conotação adjetiva ao substantivo povo, referindo-se geralmente a povo gentio. A idéia básica é a de um grupo de pessoas, ou certa massa de gente que ocupa determinada região, referindo-se também a seu aspecto político, étnico ou territorial. Seu plural, gôyim, significa nações, as nações vizinhas, nações gentias $(\mathrm{Jz} 2,23$; Is 61,11$)$ com as quais Israel não deveria se misturar nas determinações da lei e dos profetas anteriores. O profeta Jeremias fez uso da expressão no singular para referir-se às nações estrangeiras que deveriam se prostrar diante do rei da Babilônia e também à nação de Israel que estava

${ }^{21}$ PINZETTA, Inácio. "Um projeto de defesa aos estrangeiros", in Estudos Bíblicos. Petrópolis/São Leopoldo, n. 27, 1990, p. 29-37. 
sendo castigada sob domínio de outras nações (Jr 7,28; 12,17; 18,8; 25,12). Basicamente, estas nações são as mesmas para as quais o servo de lahweh no livro do profeta Isaías deveria ser luz (Is 42,6 e 49,6) e que seriam reconduzidas a lahweh através da glória de Jerusalém (60,3 e 11; 62,2 e 64,1). Especificamente no livro do Deuteronômio, gôy ou gôyim são as nações que seriam desapossadas diante de Israel na conquista de Canaã (Dt 4,38; 7,1; 9,1; 11,23), as que seriam herdadas por Israel e aquelas a quem Israel ajudaria com sua prosperidade (Dt 15,6;28,12 e 32,8). Com o passar do tempo, a expressão foi usada cada vez mais para referir-se aos gentios que não participavam da aliança com lahweh, ou seja, grupos diferenciados do ponto de vista étnico, político e territorial. Dt 4,6 e 7 refere-se à nação israelita como um grupo político e étnico (gôy) que é um povo ('am) sábio e entendido, que possui uma identidade nacional específica sendo, por isso, reconhecido por outras nações.

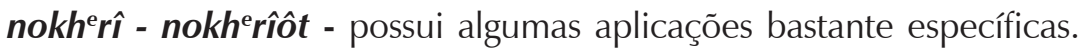
nokherî ou nékár, são variações da raiz nkr. A palavra tem muitos sentidos diferentes, nos dedicaremos apenas à aplicação da mesma no sentido de estrangeiro. Ela tem sido traduzida como estranho, estrangeiro, desconhecido, forasteiro, adventício, imigrante, exótico e intruso. A mesma raiz apenas com vocalização diferente significa desgraça ou fracasso, supõe-se que, ao utilizar nokherî ao invés de gér, o redator bíblico quisesse fazer dupla associação: estrangeiro = desgraça. O nokherî é o estrangeiro, mas estrangeiro estranho à população local, o estrangeiro que não se adapta, que permanece um estranho. Mulheres estranhas/estrangeiras são a derivação feminina plural (1 Rs 11,1 e 8; Ed 10,2.10.14.17.18.44 e Ne 13,27). São filhos de nokherî os marginalizado que estavam sendo expulsos da congregação juntamente com os eunucos (Is 56,6 e 60,10).

Em resumo, podemos perceber que as palavras são sinônimas em muitas aplicações. Todas querem referir-se ao estrangeiro. Mas a própria utilização de terminologias diferenciadas quer conotar uma diferenciação também do tipo de estrangeiro ao qual o texto bíblico se refere. Havia forasteiros e migrantes residentes. As leis especiais de proteção parecem dirigir-se majoritariamente aos forasteiros. Os migrantes residentes já possuíam uma estabilidade maior no meio dos israelitas e deveriam estar submissos a todas as leis que se aplicassem à Israel. Já o nokherî é tratado como um invasor indesejado da cultura autóctone, que invade e sequestra, não é bem-vindo e causa estranhamento. Os estrangeiros que Neemias se esforçou por eliminar em Judá nos dias de seu governo são nokherî: "Purifiquei-os de todo nokherî e restabeleci as funções referentes aos sacerdotes e aos levitas, cada um em sua tarefa" (Ne 13, 30). As mulheres estrangeiras que são expulsas da 
congregação (Ed 9 e 10) são nokh rîot. Os filhos de estrangeiros que foram expulsos da religião de lahweh juntamente com os eunucos, para os quais o $3^{0}$ Isaías toma voz de defesa, são filhos de nokherî. As leis de inclusão dos prosélitos na vida religiosa se aplicam somente aos gérim. E aparentemente as leis de exclusão referem-se especificamente aos goyîm e nokherîtot.

\begin{tabular}{l|c|c|c|c|c}
\hline \multicolumn{6}{c}{ Estrangeiros no Código Dt (Dt 12 - 26) } \\
\hline PERTINÊNCIA DA LEI & Refer. & Gér & Goy & Nokherî & Outros \\
\hline Eliminar as nações desapossadas & 12,2 & & $X$ & & \\
\hline Não cair em armadilhas das nações & $12,29-30$ & & $X$ & & \\
\hline Estrangeiros recebem do dízimo trienal & 14,29 & $X$ & & & \\
\hline Pressionar o estrangeiro a pagar dívida & 15,3 & & & $X$ & \\
\hline Israel dominará e emprestará às nações & 15,6 & & $X$ & & \\
\hline Estrangeiro na festa das semanas & 16,11 & $X$ & & & \\
\hline Estrangeiro celebrará a festa das tendas & 16,14 & $X$ & & & \\
\hline Estrangeiro não poderá ser rei & 17,15 & & & $X$ & \\
\hline Não praticar hábitos das nações & 18,14 & & $X$ & & \\
\hline Exclusão da assembléia: eunuco & 23,2 & & & & $X$ \\
\hline Exclusão da assembléia: filho bastardo & 23,3 & & & & $X$ \\
\hline Amonita e Moabita excluídos & $23,4-7$ & & & & $X$ \\
\hline Edomitas e Egípcios não abomináveis & 23,8 & & & & $X$ \\
\hline Inclusão filhos de Edomitas e Egípcios & 23,9 & & & & $X$ \\
\hline Não explorar assalariado estrangeiro & 24,14 & $X$ & & & \\
\hline Não defraudar o estrangeiro & 24,17 & $X$ & & & \\
\hline Restos da colheita para o estrangeiro & $24,19-22$ & $X$ & & & \\
\hline Apagar a memória de Amaleque da terra & 25,17 & & & & $X$ \\
\hline O estrangeiro no credo oferta de primícias & 26,5 & $X$ & & & \\
\hline O estrangeiro se alegrando nas primícias & 26,11 & $X$ & & & \\
\hline O estrangeiro já ter recebido dízimo trienal & 26,13 & $X$ & & & \\
\hline Eone en & & & \\
\hline
\end{tabular}

Fonte: elaboração própria.

As leis que estabelecem o relacionamento de Israel com as nações estrangeiras e seus habitantes encontram-se basicamente no Código da Aliança (Ex 20, 22 - 23,19), no Código Deuteronômico (Dt 12-26) e no Código da Santidade (Lv 17-26). Não queremos entrar numa longa discussão sobre as datações de cada compêndio jurídico, mas, em síntese, adotamos a corrente que data o Código da Aliança no final do séc. IX, o Código Dt no final do séc. VII aEC e o Código da Santidade seria oriundo do período do exílio - séc. 
VI-V aEC. Privilegiaremos a lei que se encontra no Código Deuteronômico cujas camadas redacionais foram bem estabelecidas por Kramer $^{22}$ e um mapeamento mais preciso pode ser encontrado numa tabela com explicações detalhadas em nossa pesquisa e que reproduzimos parcialmente aqui.. ${ }^{23}$ As cores representam: interdição (preta) e inclusão (cinza).

Não há uma só lei de interdição ou negativa se referindo aos gérim. A grande maioria de leis positivas e de inclusão é aplicável apenas aos gérim. Quanto aos gôyim, estes são vistos na lei com aspectos negativos. A única determinação do Código Dt que se aplica de forma mais ou menos positiva aos gôyim é de caráter quase imperialista, dizendo que Israel, quando dominar os povos estrangeiros, emprestará aos gôyim. As demais determinações referentes aos gôyim são leis negativas e de interdição do estrangeiro. Quanto ao terceiro grupo de estrangeiros, nokherîot, não há uma lei sequer de inclusão ou permissão referindo-se a eles.

Tanto a escrava de Naamã quanto o cuchita etíope eram pessoas regidas, pelo menos parcialmente, sob estas leis. Entretanto o texto bíblico conta suas histórias como se tais leis não fossem aplicadas no caso deles, talvez por pura negligência dos israelitas. No caso da menina, ela estava fora do território de Israel, sendo submetida à lei dos países de lá, mas o cuchita etíope estava sob perspectiva legal judaíta, mas foi preservado da destruição pela promessa direta do oráculo de lahweh. Impressiona-me que lahweh não foi seletivo quanto ao status estrangeiro ou mesmo da diversidade de gênero destas duas pessoas. lahweh honrou a ambos. E nós?

\section{Conclusão}

Com alunos de Recursos Humanos tenho discutido a questão do Apagão de Mão-de-Obra, que se dá no nível superior superespecializado e ainda mais no nível básico, para trabalhos técnicos na área de construção civil e serviços domésticos. Enfrentamos dificuldades para contratação de auxiliares de serviços gerais, empregadas domésticas, babás, faxineiras, e também os pedreiros estão se tornando muito escassos e caros.

Uma notícia na TV me chamou a atenção no final de 2011. A Pastoral do Migrante estava certificando dezenas de mulheres latinas como babás, para trabalharem no Brasil com certificação. Em 12/01/2012 o Conselho Nacional de Imigração criou doze espécies de concessões para a entrada de Haitianos

${ }^{22}$ KRAMER, Pedro. Origem e legislação do Deuteronômio.

${ }^{23}$ Cf. MARIANNO, Lília Dias. "A lei e os "fora-da-lei". Os encontros e desencontros entre lei e migrantes no Antigo Israel"; também em: IDEM. A ameaça que vem de dentro: um estudo sobre as relações entre judaítas e estrangeiros no pós-exílio em perspectiva de gênero, p. 100. 
no Brasil que venham a trabalho. ${ }^{24}$ Percebi, nos últimos meses, um número enorme de latinos no centro do Rio de Janeiro, vendendo roupas como camelôs nas ruas mais movimentadas da cidade. Trabalhando com uma comunidade de sem-teto na Central do Brasil dirigi-me ao mercado para a compra de comida num dia específico. Novamente estavam lá os latinos, vivendo por ali, comprando por ali, no meio do nosso povo mais pobre. Alguém sabe seus nomes? Será que algum deles era professor, médico ou empresário antes de vir para nossa terra à procura de oportunidades melhores?

O Brasil é um país em franco desenvolvimento, os estudos trazem muitos índices que comprovam que nosso povo está gradativamente saindo da indigência. A linha de pobreza extrema, que até dois anos atrás atingia 10\% da população agora atinge apenas 3\%. Estamos virando "primeiro mundo". Não devemos assumir o imperialismo do primeiro mundo humilhando ao estrangeiro porque ele está em nossa terra, muitas vezes se despindo de seu status social originalmente elevado, para fazer um trabalho de base essencial, que nós, por elitismo intelectual não queremos mais fazer. O desenvolvimento de nosso país também está sendo construído com o esforço do estrangeiro que habita entre nós.

"Não oprimirás o estrangeiro..." é o que diz o texto bíblico. O estrangeiro não é um anônimo, ele tem nome, ele tem identidade. lahweh honra o estrangeiro. Nós não somos melhores que Deus, esta honra precisa ser também exercida por nós.

Deus conosco!

Em memória de Milton Schwantes ${ }^{25}$

(1946-2012)

\section{Bibliografia}

COULIBALY, Issiaka. "Comentário sobre Jr 38,1-14", in ADEYEMO, Tokunboh (ed.). Comentário Bíblico Africano. São Paulo: Mundo Cristão, 2010, p. 931-932.

DREHER, Carlos. "Escravos no Antigo Testamento", in Estudos Bíblicos, Petrópolis: Vozes, n. 18: Escravidão e escravos na Bíblia, 1998, p. 16.

HELMINIAK, Daniel. O que a Bíblia realmente diz sobre a homossexualidade. São Paulo: Summus, 1998.

${ }^{24}$ Conselho Nacional de Imigração cria visto especial de trabalho para haitianos. Acessado em: 20/02/2012 Disponível em: http://agenciabrasil.ebc.com.br/noticia/2012-01-12/conselhonacional-de-imigracao-cria-visto-especial-de-trabalho-para-haitianos.

${ }^{25}$ Tenho com o professor Schwantes uma enorme gratidão e uma dívida impagável pela forma como ensinou fazer ciência exegética com a Bíblia que se transformava em esperança para os pobres, oprimidos e marginalizados de nossas sociedades. Dedico este artigo ao mestre, com carinho, que veio a falecer enquanto eu terminava de escrever este ensaio. 
KRAMER, Pedro. Origem e legislação do Deuteronômio: programa de uma sociedade sem empobrecidos e excluídos. São Paulo: Paulinas, 2006.

MARIANNO, Lília Dias. A ameaça que vem de dentro: um estudo sobre as relações entre judaítas e estrangeiros no pós-exílio em perspectiva de gênero. [Dissertação de Mestrado] São Bernardo do Campo, 2007.

. "A lei e os "fora-da-lei". Os encontros e desencontros entre lei e migrantes no Antigo Israel", in Revista de Interpretação Bíblica Latino-Americana, n. 63, 2009.

. "Impureza: Sexualidade e saúde pública no judaísmo do período Persa", in Revista Vértices, n. 11, São Paulo: DLO-FFLCH-USP, 2011, p. 110-130.

MENA LOPEZ, Maricel. "Ebed-Melec, o cuchita, salva Jeremias da cisterna. Um testemunho de seguimento profético no tempo do cerco e queda de Jerusalém (Jeremias 38,7-13 e 39,15-18)", in Estudos Bíblicos, Profetas e profecias: novas leituras, n. 73, 2002, p. 46-48.

MONTALVÃO, Sérgio Aguiar. A homossexualidade na Bíblia Hebraica. Um estudo sobre a prostituição sagrada no Antigo Oriente Médio. [Tese doutoral-USP] FFLCHDLO-PPGLHLCJ. São Paulo, 2009.

PINZETTA, Inácio. "Um projeto de defesa aos estrangeiros", in Estudos Bíblicos, Petrópolis/São Leopoldo, n. 27, 1990, p. 29-37.

VENTURA, Maria Cristina. “Um cuchita fala como o Deus do profeta! - uma leitura de Jeremias 38,7-13", in Revista de Interpretação Bíblica Latino-Americana, n. 54, 2006, p. 71-72.

\section{Abstract}

This is a work for immigrants! Contributions on migration, gender, and work in the First Testament

This assay presents a biblical approach that dialogue with migration, job and identity. It privileges a gender approach and African plus Caribbean perspective of biblical interpretation. The initial and final challenges are the Brazilian experience of migration in foreign countries also of foreign people in Brazil. The migrant, in servile condition, in poverty and marginalization, always do the job that the autochthon doesn't want to do. The Naaman servant (2 Kg 5, 1-27) and the Ethiopian eunuch, servant of Zedechias' palace (Jr 38,1-13), people without a name, were liberation instruments for those which were close through their jobs.

Key-words: Migration; Job; Identity; Gender; Black People.

Recebido para publicação em 11/10/2011.

Aceito para publicação em 02/05/2012. Received for publication in October, 11 $1^{\text {th }}, 2011$.

Accepted for publication in May, 02 ${ }^{\text {th }}, 2012$. 